\title{
THE INCIDENCE OF HEPATITIS E VIRUS IN DOMESTIC PIGS
}

\author{
Jackova, A., Mandelik, R., Novotny, J., Salamunova, S., Vilcek, S. \\ University of Veterinary Medicine and Pharmacy, Kosice, \\ Slovakia \\ anna.jackova@uvlf.sk
}

\section{ABSTRACT}

Hepatitis E virus (HEV) is the causative agent of hepatitis $\mathrm{E}$ - an emerging zoonotic disease distributed worldwide. The aim of this study was to determine the prevalence of HEV in Slovakian domestic pigs, as this has not been studied yet. Clinical samples $(n=269)$ from fourteen randomly selected domestic pig farms for three different age categories of pigs were analysed and the subsequently detected isolates were genetically characterized. The reverse transcriptase polymerase chain reaction (RT-PCR) analysis revealed that 32 pigs (11.9\%) of all age categories were HEV RNA positive. The highest occurrence was detected in fattening pigs $(14.8 \%)$ and the lowest in weaning pigs (12.5\%). The HEV RNA was not observed at all in the youngest category (the suckling piglets). The phylogenetic analysis revealed that all Slovak HEV isolates clustered into two genetic groups of the genotype HEV-3.

Key words: domestic pig; hepatitis E virus (HEV); rectal swab

\section{INTRODUCTION}

Hepatitis E virus (HEV), the causative agent of hepatitis $\mathrm{E}$, is a small non-enveloped virus with a virion size of approximately $27-34 \mathrm{~nm}$ in diameter containing a positivesense single-stranded RNA with a length of $6.6-7.3 \mathrm{~kb}$. The genome is organized into three open reading frames (ORF1-3). ORF1 and 3 encoded non-structural proteins and ORF2 encodes the viral capsid protein [13]. HEV belongs to the Hepeviridae family, which has recently been split into two genera, Orthohepevirus and Piscihepevirus. Genus Orthohepevirus is classified into four species designated Orthohepeviruses A-D. Orthohepevirus A is formed by seven genotypes, that infect humans (HEV-1, -2, -3, -4 and -7), pigs (HEV-3 and -4), rabbit (HEV-3), wild boar (HEV-3, -4, -5 and -6), mongoose (HEV-3), deer (HEV-3), yak (HEV-4) and camel (HEV-7) [23].

After the first characterization of HEV in domestic pigs by Meng et al. [13] in the USA, the virus has been detected in the same animal species in many other countries including Canada [18], Netherlands [25], United Kingdom [1], Italy [3], France [21] and Spain [11]. At the same time 
swine HEV has been detected and characterized in such neighbouring countries as Hungary and Czechia $[8,4]$.

Domestic pigs are believed to be an important source of zoonotic transmission of HEV-3 and HEV-4 and they are responsible for sporadic human hepatitis E cases worldwide [17]. It is critical to know the prevalence of HEV in domestic pig farms so as to be able to assess the health situation of the pig population and thus estimate the risk to public health.

The objective of this study was: to observe HEV in domestic pigs in Slovakia, which has not been determined as yet: to characterize the genetically detected isolates; and to gain an insight into the incidence of HEV in the Slovak domestic pig population.

\section{MATERIALS AND METHODS}

\section{Samples}

Clinical samples (rectal swabs, $n=269$ ) were obtained from the pigs of fourteen randomly selected Slovakian domestic pig farms. Three different age categories were distinguished: suckling piglets $(<28$ days, $\mathrm{n}=35)$, weaners (28-70 days, $\mathrm{n}=112$ ), and fattening pigs ( $>70$ days, $\mathrm{n}=122$ ). No clinical sign of any disease was observed. The health status of each pig was evaluated by a qualified veterinarian on each farm.

\section{Isolation of RNA and synthesis of cDNA}

The rectal swabs were processed in the laboratory by elution into $1 \mathrm{ml}$ of $0.01 \mathrm{~mol}^{-1}$ PBS (Merck Millipore Corp., USA) for $30 \mathrm{~min}$. The eluted solution was vortexed at $2000 \mathrm{rev} . \mathrm{min}^{-1}$ for $3 \mathrm{~min}$ and then centrifuged at $17500 \times \mathrm{g}$ for $5 \mathrm{~min}$. The total RNA was isolated using TRIzol Reagent (Life Technologies, USA) from $200 \mu$ l of a sample according to the manufacturer's instructions and dissolved in $20 \mu \mathrm{l}$ of molecular biology grade water (Merck, GmbH, Germany). Samples with aliquots of the isolated RNA were stored at $-80^{\circ} \mathrm{C}$. The cDNA was synthesized in a $20 \mu \mathrm{l}$ reaction mixture comprising $5 \mu \mathrm{l}$ of isolated RNA, $5 \mu \mathrm{M}$ of random hexamers (Invitrogen, USA), $50 \mu \mathrm{l}$ dNTPs (Thermo Fisher Scientific, Inc., USA), $200 \mathrm{U}$ RevertAid Premium reverse transcriptase with 1xRT buffer (Thermo Fisher Scientific, Inc., USA), 20 U RNase inhibitor (Takara Bio, Inc., Japan), and molecular biology grade water (Merck, GmbH, Germany). The mixture was incubated at $65^{\circ} \mathrm{C}$ for $5 \mathrm{~min}$ and then chilled on ice to destroy the RNA secondary structure. Subsequently, the mixture was incubated at $25^{\circ} \mathrm{C}$ for $10 \mathrm{~min}$, then at $50^{\circ} \mathrm{C}$ for $30 \mathrm{~min}$ to synthesise cDNA, and at $85^{\circ} \mathrm{C}$ for $5 \mathrm{~min}$ to terminate the reaction.

\section{Detection of HEV by nested reverse transcriptase polymerase chain reaction (RT-PCR)}

The detection of the partial HEV genome was based on the amplification of a 242 bp fragment of ORF1 gene using outer and inner primers published by Erker et al. [5]. The PCR reaction mixture $(25 \mu \mathrm{l})$ was composed of $1 \mathrm{x}$ ThermoPol reaction buffer (New England Biolabs, Inc., USA), $200 \mu \mathrm{M}$ dNTPs (Thermo Fisher Scientific, Inc., USA), $0.3 \mu \mathrm{M}$ of outer primers, $0.5 \mathrm{U}$ Taq DNA polymerase (New England Biolabs, Inc., USA), $2 \mu \mathrm{l}$ cDNA, and molecular grade water (Merck, GmbH, Germany). The first PCR was run with the following thermal profile: 1 cycle at $95^{\circ} \mathrm{C}$ for $1 \mathrm{~min}$, and $35 \mathrm{cycles}$ with denaturation at $95^{\circ} \mathrm{C}$ for $30 \mathrm{~s}$, annealing at $55^{\circ} \mathrm{C}$ for $1 \mathrm{~min}$, and extension at $68^{\circ} \mathrm{C}$ for $1 \mathrm{~min}$, and a final extension at $68^{\circ} \mathrm{C}$ for $5 \mathrm{~min}$. In the second PCR inner primers, a similar thermal profile was used. The size of the PCR products was checked by electrophoresis in $2 \%$ agarose gel after staining with GelRedTM (Biotium, Inc., USA) and visualization by Gel Doc EZ imager (Bio-Rad Laboratories, Inc., USA).

\section{Sequencing of DNA and phylogenetic analysis of HEV}

Purified PCR products were sequenced using an automatic sequencer ABI PRISM (Microsynth Austria, GmbH, Austria). The sequences from both strands of the PCR products were determined with the same primers as those used for the nested PCR amplification. Partial ORF1 sequences (242 nt) were edited and aligned by the computer programme SeqMan, EditSeq and MegAlign (Lasergene, DNASTAR, Inc. USA). The phylogenetic tree was constructed by the neighbour-joining method using MEGA $4.0[24]$.

\section{RESULTS}

The results of the prevalence of hepatitis E virus in the domestic pigs are summarized in Table 1. The RT-PCR analysis of 269 enteric samples revealed that 32 pigs (11.9\%) of all age categories were HEV RNA positive. When looking across age categories, HEV RNA was most often detected 


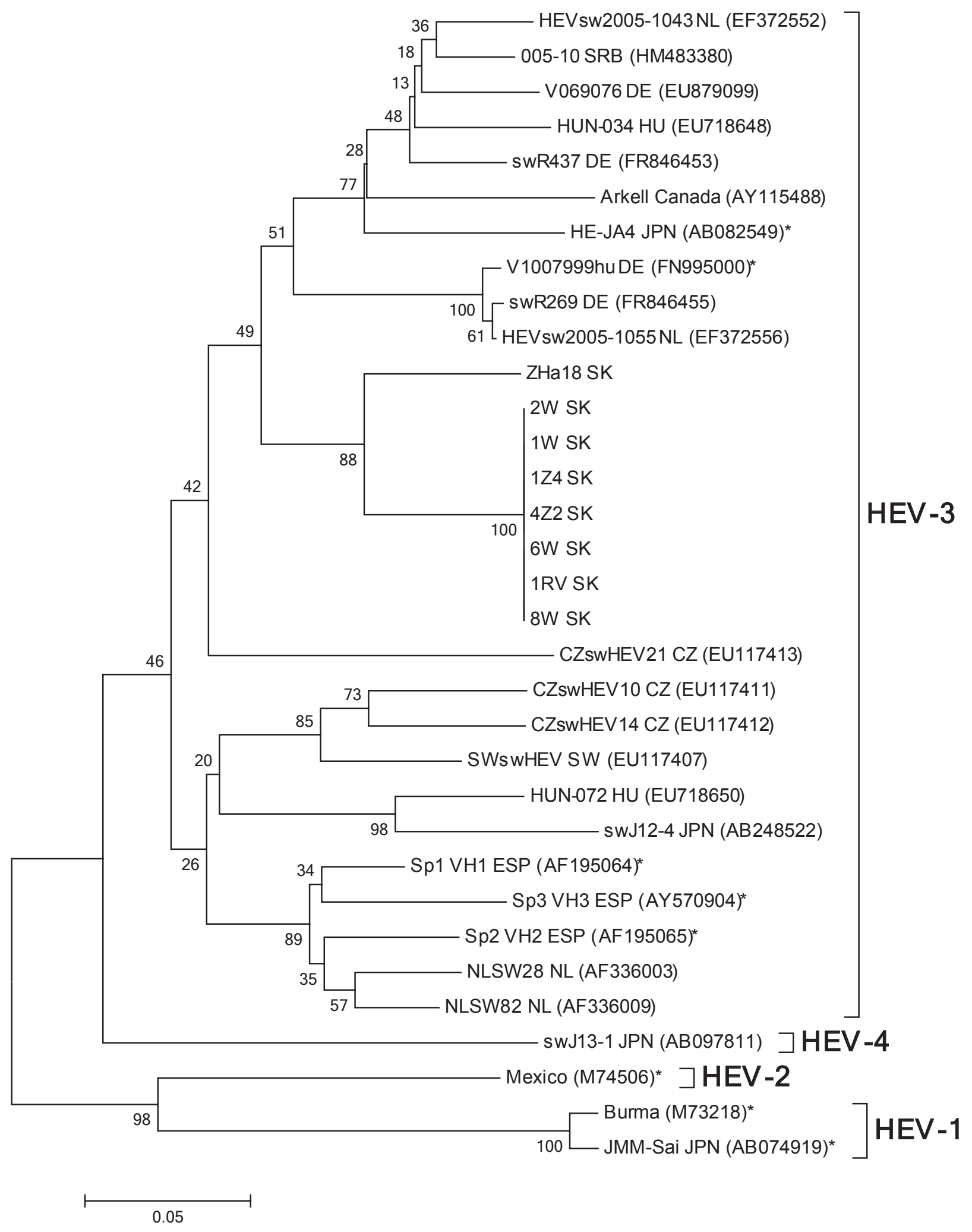

Fig. 1. The phylogenetic tree based on the partial ORF1 region of HEV-1, -2, -3, -4 genotypes All HEV isolates from GenBank - in parentheses with GenBank Acc. No.

Human HEV isolates from GenBank - in parentheses with GenBank Acc. No., in addition labelled * Slovak swine HEV isolates without GenBank Acc. No. in parentheses 
Table 1. The incidence of HEV in different age categories of domestic pigs

\begin{tabular}{lccc}
\hline $\begin{array}{c}\text { Age category } \\
\text { [days] }\end{array}$ & $\begin{array}{c}\text { Number } \\
\text { of samples } \\
{[\mathrm{n}]}\end{array}$ & $\begin{array}{c}\text { Number } \\
\text { of HEV RNA } \\
\text { positive } \\
{[\mathrm{n}]}\end{array}$ & $\begin{array}{c}\text { Percentage } \\
\text { of HEV RNA } \\
\text { positive } \\
{[\%]}\end{array}$ \\
\hline $\begin{array}{l}\text { Suckling piglets } \\
<28 \text { days }\end{array}$ & 35 & 0 & 0 \\
$\begin{array}{l}\text { Weaners } \\
28-70 \text { days }\end{array}$ & 112 & 14 & 12.5 \\
$\begin{array}{l}\text { Fattening } \\
>70 \text { days }\end{array}$ & 122 & 18 & 14.8 \\
\hline Total & $\mathbf{2 6 9}$ & $\mathbf{3 2}$ & $\mathbf{1 1 . 9}$ \\
\hline
\end{tabular}

in fattening pigs (14.8\%), while a lower prevalence was detected in weaned piglets $(12.5 \%)$. HEV RNA was not observed in suckling piglets. Positive HEV RNA samples were detected only on two pig farms from all of the 14 analysed farms.

Phylogenetic analysis revealed that Slovak HEV isolates clustered into two genetic groups (Fig. 1). All Slovak $\mathrm{HEV}$ isolates were typed as HEV-3. The comparison of nucleotide sequences of Slovak HEV isolates to each other showed $81.0-100 \%$ identity. The identity of the nucleotide sequences of Slovak HEV isolates with HEV isolates from neighbouring countries, Czechia and Hungary, was observed $81.8-86.8 \%$ and $80.686 .8 \%$, respectively.

\section{DISCUSSION}

After the first characterization of swine HEV in USA by Meng et al. [13], the virus has been detected in the same species in many countries including Spain, Netherlands, Canada, United Kingdom $[19,25,18,1]$ and recently has been described in Africa [16].

Our study investigated the occurrence of HEV in clinically healthy pigs on Slovak domestic pig farms indicating a relatively high presence of HEV (11.9\%). Very low occurrence of RNA HEV (3\%) was observed in faeces samples collected in a Czech slaughterhouse, similarly to clinically healthy pigs [4]. Besides Czechia, swine HEV was detected and characterized in neighbouring Hungary. HEV infection among domestic swine appears to be at quite a high level (39\%) on the Hungarian swine farms [20].
This study detected HEV in clinically healthy pigs. Most of the published studies are based on the detection in naturally or experimentally infected pigs $[2,9,19]$.

Up to now only a few studies have been aimed at HEV detection in relation to the age of pigs. Although two published studies pointed out that 2-4 months old pigs usually showed HEV infection [13, 14], our study demonstrated that the virus can be detected in pigs younger than 2 months. In our study, we have observed the occurrence of HEV in $12.5 \%$ of weaned piglets ( $28-70$ days old). The highest percentage of HEV (14.8\%) was observed in the fattening category (>70 days old). Similarly, the highest percentage of pigs with RNA HEV (36 \%) was observed by Forgách et al. [8] in a comparable age group (1116 weeks old) of pigs.

Contrary to the results indicating a low HEV prevalence (9\%) in 1-4 week old piglets detected by Forgá ch et al. [8], we failed to detect HEV in the youngest age category, the suckling piglets ( $<28$ days old). The protective role of passive immunity is probably the reason for the absence of $\mathrm{HEV}$ in suckling piglets in our study. We assume that the influence of maternal antibodies in this age category of pigs has a high protective effect.

By RT-PCR detection in the Netherlands, $22 \%$ and $55 \%$ of the pig farms were found HEV-positive in 1999 and 2005 , respectively [22]. In the USA, $54 \%$ and $40 \%$ of the pig farms were found HEV-positive in 2002 and 2005, respectively $[10,12]$. Surprisingly, HEV RNA was detected in $100 \%$ of the 6 pig farms located in northern Italy [3], in $73 \%$ of the pig farms investigated in Shanghai [15]. In Spain the prevalence of HEV among pig farms increased from $38 \%$ in 2006 to $76 \%$ in 2007 [6, 7].

The nucleotide sequences of ten HEV isolates from Slovakia were aligned and compared to each other and to the selected strains deposited in GenBank. The comparison of the nucleotide sequences identity of Slovak HEV isolates to each other showed high identity in nearly $100 \%$. By comparison of nucleotide sequences from neighbouring countries, Czechia and Hungary, an identity within 80.6-86.8\% was observed. By phylogenetic analysis of partial ORF1, we found that Slovak isolates clustered into two genetic groups (Fig. 1). All Slovak HEV isolates were typed as genotype $\mathrm{HEV}-3$, which is a common genotype of animal, including human isolates. This is considered an important characteristic of the potential source of human infections. 


\section{CONCLUSIONS}

In our study we investigated the prevalence of HEV on domestic pig farms in Slovakia which has not been addressed before. The analysis of three different age categories of domestic pigs showed some differences. The highest occurrence was observed in the fattening category and lowest in weaned piglets. HEV RNA was not observed in the youngest category (the suckling piglets). The phylogenetic analysis revealed that the Slovak HEV isolates clustered into two genetic groups. All Slovak HEV isolates were typed as HEV-3, which are capable of infecting humans.

In the near future, we would like to extend our investigations to other domestic pig farms in Slovakia and to characterize more HEV isolates.

\section{ACKNOWLEDGEMENT}

This study was supported by the project INFEKTZO$\mathrm{ON}-$ Center of excellence for infectious disease and zoonosis ITMS 26220120002 (operational programme of research and development) financed by European Union funds for regional improvement.

\section{REFERENCES}

1. Banks, M., Heath, G.S., Grierson, S. S., King, D. P., Gresham, A., Girones, R. et al., 2004: Evidence for the presence of hepatitis E virus in pigs in the United Kingdom. Vet. Rec., 154, 223-227.

2. Cooper, K., Huang, F. F., Batista, L., Rayo, C. D., Bezanilla, J. C., Toth, T. E. et al., 2005: Identification of genotype 3 hepatitis $\mathrm{E}$ virus (HEV) in serum and faecal samples from pigs in Thailand and Mexico, where genotype 1 and 2 HEV strains are prevalent in the respective human populations. J. Clin. Microbiol., 43, 1684-1688.

3. Di Bartolo, I., Martelli, F., Inglese, N., Pourshaban, M., Caprioli, A., Ostanello, F. et al., 2008: Widespread diffusion of genotype 3 hepatitis $\mathrm{E}$ virus among farming swine in Northern Italy. Vet. Microbiol., 132, 47-55.

4. Di Bartolo, I., Diez-Valcarce, M., Vasickova, P., Kralik, P., Hernandez, M., Angeloni, G. et al., 2012: Hepatitis E virus in pork production chain in Czech Republic, Italy, and Spain, 2010. Emerg. Infect. Dis., 18, 1282-1289.
5. Erker, J.C., Desai, S.M., Mushahwar, I. K., 1999: Rapid detection of Hepatitis E virus RNA by reverse transcriptionpolymerase chain reaction using universal oligonucleotide primers. J. Virol. Methods, 81, 109-113.

6. Gracia, M. T., 2006: Detection of hepatitis E virus shedding in faeces of pigs at different stages of production using reverse transcription polymerase chain reaction. J. Vet. Diagn. Invest., 18, 462-465.

7. Fernandez-Barredo, S., Galiana, C., Garcia, A., GomezMunoz, M.T., Vega, S., Rodriguez-Iglesias, M.A. et al., 2007: Prevalence and genetic characterization of hepatitis $\mathrm{E}$ virus in paired samples of faeces and serum from naturally infected pigs. Can. J. Vet. Res., 71, 236-240.

8. Forgách, P., Nowotny, N., Erdélyi, K., Boncz, A., Zentai, J., Szucs, G. et al., 2010: Detection of hepatitis E virus in samples of animal origin collected in Hungary. Vet. Microbiol., $143,106-116$.

9. Halbur, P.G., Kasorndorkbua, C., Gilbert, C., Guenette, D., Potters, M.B., Purcell, R.H. et al., 2001: Comparative pathogenesis of infection of pigs with Hepatitis E viruses recovered from a pig and a human. J. Clin. Microbiol., 39, 918-923.

10. Huang, F. F., Haqshenas, G., Guenette, D. K., Halbur, P. G., Schommer, S.K., Pierson, F.W. et al., 2002: Detection by reverse transcription-PCR and genetic characterization of field isolates of swine hepatitis E virus from pigs in different geographic regions of the United States. J. Clin. Microbiol., 40, 1326-1332.

11. Jiménez de Oya, N., de Blas, I., Blázquez, A.B., MartinAcebes, M. A., Halaihel, N., Gironés, O. et al., 2011: Widespread distribution of hepatitis $\mathrm{E}$ virus in Spanish pig herds. BMC Res. Notes, 4, 412-419.

12. Kasorndorkbua, C., Opriessnig, T., Huang, F. F., Guenette, D. K., Thomas, P. J., Meng, X. J. et al., 2005: Infectious swine hepatitis E virus is present in pig manure storage facilities on United States farms, but evidence of water contamination is lacking. Appl. Environ. Microbiol., 71, 7831-7837.

13. Meng, X.J., Purcell, R.H., Halbur, P.G., Lehman, J.R., Webb, D.M., Tsareva, T.S. et al., 1997: A novel virus in swine is closely related to the human hepatitis E virus. Proc. Natl. Acad. Sci. USA, 94, 9860-9865.

14. Meng, X. J., Halbur, P. G., Shapiro, M.S., Govindarajan, S., Bruna, J.D., Mushahwar, I.K., 1998: Genetic and experimental evidence for cross-species infection by swine hepatitis E virus. J. Virol., 72, 9714-9721. 
15. Ning, H., Yu, S., Zhu, Y., Dong, S., Yu, R., Shen, S. et al., 2008: Genotype 3 hepatitis $E$ has been widespread in pig farms of Shanghai suburbs. Vet. Microbiol., 126, 257-263.

16. Owolodun, O. A., Gerber, P. F., Gimenez-Lirola, L. G., Kwaga, J. K., Opriessnig, T., 2014: First report of hepatitis E virus circulation in domestic pigs in Nigeria. Am. J. Trop. Med. Hyg., 91, 699-704.

17. Pavio, N., Meng, X. J., Renou, C., 2010: Zoonotic hepatitis E: Animal reservoirs and emerging risks. Vet. Res., 41, 46.

18. Pei, Y., Yoo, D., 2002: Genetic characterization and sequence heterogeneity of a Canadian isolate of swine hepatitis E virus. J. Clin. Microbiol., 40, 4021-4029.

19. Pina, S., Buti, M., Cotrina, M., Piella, J., Girones, R., 2000: HEV identified in serum from humans with acute hepatitis and in sewage of animal origin in Spain. J. Hepatol., 33, $826-833$

20. Reuter, G., Fodor, D., Forgách, P., Kátai, A., Szucs, G., 2009: Characterization and zoonotic potential of endemic hepatitis E virus (HEV) strains in humans and animals in Hungary. J. Clin. Virol., 44, 277-281.
21. Rose, N., Lunazzi, A., Dorenlor, V., Merbah, T., Eono, F., Eloit, M. et al., 2011: High prevalence of hepatitis E virus in French domestic pigs. Comp. Immunol. Microbiol. Infect. Dis., 34, 419-427.

22. Rutjes, S. A., Lodder, W., Bouwknegt, M., de Roda Husman, A M., 2007: Increased hepatitis E virus prevalence on Dutch pig farms from 33 to $55 \%$ by using appropriate internal quality controls for RT-PCR. J. Virol. Methods, 143, 112-116.

23. Smith, D. B., Simmonds, P., Jameel, S., Emerson, S. U., Harrison, T. J., Meng, X.J. et al., 2014: Consensus proposals for classification of the family Hepeviridae. J. Gen. Virol., 96, $1191-1192$

24. Tamura, K., Dudley, J., Nei, M., Kumar, S., 2007: MEGA 4: Molecular Evolutionary Genetics Analysis (MEGA) software version 4.0. Mol. Biol. Evol., 24, 1596-1599.

25. Van der Poel, W.H.M., Verschoor, F., van der Heide, R., Herrera, M. I., Vivo, A., Kooreman, M. et al., 2001: Hepatitis $\mathrm{E}$ virus sequences in swine related to sequences in humans, the Netherlands. Emerg. Infect. Dis., 7, 970-976.

Received July 24, 2017

Accepted September 4, 2017 